\title{
Interaction of two key pelagic species in the Humboldt Current: euphausiid predation on anchoveta eggs estimated by immunoassays
}

\author{
M. Cristina Krautz ${ }^{1, *}$, Leonardo R. Castro ${ }^{1}$, Margarita González ${ }^{2}$ \\ ${ }^{1}$ Laboratorio de Oceanografía Pesquera y Ecología Larval (LOPEL), Departamento de Oceanografía, \\ Universidad de Concepción, Casilla 160-C Concepción, Chile \\ ${ }^{2}$ Departamento de Bioquímica Clínica e Inmunología, Universidad de Concepción, Casilla 237, Concepción, Chile
}

\begin{abstract}
The euphausiid Euphausia mucronata and anchoveta Engraulis ringens are extremely abundant key components of the pelagic community of the Humboldt Current, and utilize a large fraction of primary production in the euphotic zone. Despite the economic importance of the Peruvian anchoveta, little information exists on the causes of mortality during their early life stages. In this study we: (1) detected and quantified E. mucronata predation on anchoveta eggs in Northern Chile during the winter peak spawning season of 2000 using enzyme-linked immunosorbent assay (ELISA); and (2) estimated the fraction of total natural mortality of anchoveta eggs produced by euphausiid predation. Immunoassay with polyclonal antibodies detected $0.1 \mu \mathrm{g}$ of anchoveta egg proteins. Potential cross-reactions with proteins of coastal fish eggs were eliminated after the use of electrophoresis, Western blotting and ELISA. Protein detection time in euphausiid guts was $9 \mathrm{~h}$ $\left(13^{\circ} \mathrm{C}\right)$ and egg protein decay rate was $0.0385 \mathrm{~h}^{-1}$. Geostatistical analysis identified a large area of egg abundance, and a smaller secondary egg aggregation within the area covered in the regular spawning biomass stock assessment survey in northern Chile (daily egg production method sampling grid). Eighteen percent of total captured euphausiids within the main aggregation of eggs provided positive reactions, indicating anchoveta egg proteins in their guts. Natural mortality rate calculated at the main spawning area was $0.868 \mathrm{~d}^{-1}$. The potential euphausiid consumption of eggs in this area varied from $3.9 \times 10^{12}$ to $4.4 \times 10^{12}$ eggs d $\mathrm{d}^{-1}$. Euphausiid predation accounted for 24 to $27 \%$ of natural mortality. When added to mortality rate estimates resulting from anchoveta cannibalism in the Humboldt Current, our results suggest that half of the daily anchoveta egg production dies daily. Accordingly, these estimates challenge classical ideas of trophic webs that do not consider either young developmental stages or interspecific interaction schemes for control of dominant species in pelagic systems.
\end{abstract}

KEY WORDS: Predation - Euphausiids - Anchoveta - Engraulis ringens - Humboldt Current · Egg mortality · Ichthyoplankton

\section{INTRODUCTION}

In the highly productive upwelling systems of the California and Humboldt Currents, euphausiids and anchovies are abundant and key components of the pelagic community (Cury et al. 2000, Gonzalez et al. 2000). In the central area of the Humboldt Current (northern Chile), euphausiids channel much of the primary production to higher trophic levels (i.e. fishes) and export carbon and energy from the euphotic zone to the subsurface layers via pellet production and/or vertical migration (Escribano et al. 2000, Gonzalez et al. 2000). Like other crustaceans, euphausiids are also active predators of copepods, fish eggs and larvae (Bailey \& Houde 1989, Gibbons et al. 1991, Bailey et al. 1993, Theilacker et al. 1993). In laboratory experiments, estimations of northern anchovy larval mortality rates produced by euphausiid predation can reach 
17 larvae $\mathrm{h}^{-1}$ (Theilacker \& Lasker 1974). In turn, anchovies also feed on phytoplankton and very intensively on zooplankton, reaching high biomasses in upwelling systems where they constitute some of the most important fisheries.

Euphausia mucronata is the most abundant and largest euphausiid in the Humboldt Current. This vertically migrating species is capable of withstanding very low oxygen concentrations in the Equatorial Subsurface Waters (ESSW). During their daily migration to shallower layers at night, they become one of the most important phytoplankton consumers in the pelagic system in northern Chile (Gonzalez et al. 2000). E. mucronata shares its shallow nocturnal residence with anchoveta Engraulis ringens, a small-sized coastal spawning fish also located within the Humboldt Current (Castro et al. 2000, Llanos-Rivera \& Castro 2004). The anchoveta is one of the most important fishery resources in northern Chile, from which more than 1 million tons were captured in 2000 (see www. sernapesca.cl). Throughout its wide latitudinal range (4 to $42^{\circ} \mathrm{S}$, Serra et al. 1979), this species reproduces mainly during winter and early spring, a season in which offshore transport in the surface Ekman layer is reduced when compared with the summer upwelling season (Castro et al. 2000, Castro 2001). Despite previous knowledge of the euphausiids' capability to feed on fish eggs and the overlap in night-time distribution of E. mucronata and E. ringens, no information exists on any potential trophic relationship between these 2 key species of the upwelling system in the Humboldt Current.

The understanding of the trophic relationship between pelagic crustacean predators and their prey has been difficult because crustaceans macerate their prey, which are therefore very difficult to identify in gut remains. The growing application of immunochemical techniques in ecological issues has allowed us to determine predation rates exerted by euphausiids on a variety of prey, as well as estimate the relative importance of predation compared with other sources of mortality. This information could be very useful to the improvement of our understanding of population fluctuations of commercially important species such as anchovies in upwelling areas that are routinely assessed for fisheries purposes (Theilacker et al. 1993). Utilizing an immunochemical technique, this study explored the relationship between 2 key components of the highly productive Humboldt Currentanchovetas and euphausiids. Specifically, we: (1) used enzyme-linked immunosorbent assay (ELISA) to detect and quantify euphausiid Euphausia mucronata predation on anchoveta Engraulis ringens eggs in northern Chile during the winter peak spawning season in 2000; and (2) estimated the fraction of total natural mortality of anchoveta eggs in that area caused by euphausiid predation. The results presented here are particularly relevant given that both euphausiids and anchovies are considered key species in terms of energy and carbon flux in the pelagic ecosystem of most coastal upwelling areas of the Humboldt Current.

\section{MATERIALS AND METHODS}

Study area and fieldwork. The study area corresponds to the historical central section of the principal anchoveta spawning area in northern Chile (Serra et al. 1979), which is located between Iquique $\left(20^{\circ} 25^{\prime} \mathrm{S}\right)$ and Antofagasta $\left(23^{\circ} 40^{\prime} \mathrm{S}\right)$ and from the coast to 60 nautical miles (n mile) offshore. This area is a transition zone where warm, saline waters occur principally in summer (Subtropical Surface Water, temperature 16 to $24^{\circ} \mathrm{C}$, salinity 34.9 to 35.3 ) along with colder, low salinity waters that are present in the area for most of the year (SubAntartic Surface Water, temperature 9 to $15^{\circ} \mathrm{C}$, salinity 33 to 34.3 ). Intermittent upwelling events of ESSW characterized by low oxygen concentration, low temperature and high nutrient concentration also occur in the coastal zone throughout the year (Fuenzalida 1991).

The survey consisted of a grid with 292 stations distributed among 36 transects sampled on board RV 'Carlos Porter' during the second half of August 2000 (Fig. 1). August corresponds to the middle of the anchoveta peak spawning season in which south winds are the slowest during the year and, hence, when exportation of eggs from the coastal zone is expected to be minimized (Castro et al. 2000). This area is an important fraction of the total area utilized to assess anchoveta spawning biomass using the daily egg production method (DEPM). This stock assessment methodology allows the initial number of spawned eggs and total daily mortality to be obtained by utilizing data of egg abundance at age.

The collection methodology was based on standard protocols used in DEPM cruises; details of DEPM stock assessment methods can be found in Picquelle \& Stauffer (1985). Anchoveta eggs and zooplankton (euphausiids) samples were obtained using a CalVET net (version PAIROVET, $0.05 \mathrm{~m}^{2}$ mouth area, $150 \mu \mathrm{m}$ mesh opening) hauled vertically from $70 \mathrm{~m}$ depth. Complementary information was obtained from continuous underway fish egg sampler (CUFES) (Checkley 2000) samples collected at $3 \mathrm{~m}$ depth. Once on board, actively swimming euphausiids collected by the CalVET net were quickly removed from one of the cod ends and frozen in liquid nitrogen for later analysis. The rest of the sample was preserved in 5\% formaldehyde buffered with borax for later anchovy egg sorting and staging. The CUFES samples were utilized to 


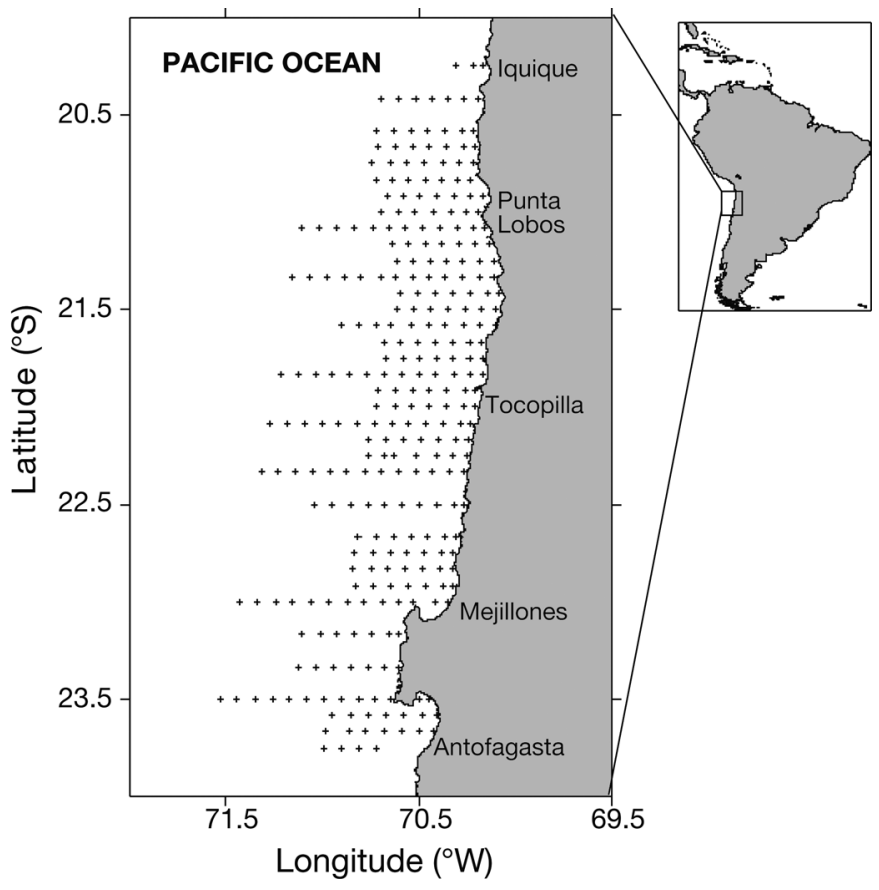

Fig. 1. Location of stations (+) of Engraulis ringens spawning biomass stock assessment cruise (daily egg production method, DEPM), August (winter) 2000

verify euphausiid presence or absence at the different stations (see capturability analyses below). Additionally, at each station, records of temperature and salinity were obtained with a CTD SeaBird 19. From these profiles, only temperature data obtained at $10 \mathrm{~m}$ depth was utilized in this study for egg staging and aging (see below).

Anchoveta spawning area. To estimate daily anchoveta egg production and natural mortality rates, the spawning area was determined by geostatistical analyses of egg abundance. Analyses were performed in 2 steps: the estimation of the variogram parameters through experimental spatial-located data (structural analysis) followed by kriging for interpolation (Matheron 1963, Petitgas 1996). The standardized variogram was adjusted by minimizing the minimum squares weighted by the number of pairs by lag (weighted minimum squares, WMS) (Cressie 1993)

$$
\min \sum_{i=1}^{H} N\left(h_{i}\right)\left(\frac{\bar{\gamma}\left(h_{i}\right)}{\gamma\left(h_{i}\right)}-1\right)^{2}
$$

where $N\left(h_{i}\right)$ is the number of the pairs in lag $\left(h_{i}\right)$ involved in the variogram estimation, $\gamma\left(h_{i}\right)$ is the experimental variogram and $\bar{\gamma}\left(h_{i}\right)$ is the theoretical variogram.

The selection of the best search parameters (cross validation) was performed using a summary statistic of error distribution (Mean Square Error, MSE) (Isaaks \& Srivastava 1989, p 263). The kriging interpolation was obtained using a regular grid of 18 lines and 43 columns of $5 \times 5 \mathrm{n}$ mile. With this information, we obtained a contour map that defined the main anchoveta spawning area within the study area.

Egg staging and aging. Before estimating daily egg production $P_{0}$ and natural mortality rate $Z$, all eggs were staged and aged (in d). Anchoveta eggs were staged using the 11 basic morphological stages described for northern anchovy by Moser \& Ahlstrom (1985). The stage duration was estimated using the temperature-dependent age-at-stage model proposed for Engraulis ringens in northern Chile by Soto et al. (2005)

$$
y_{i T}=9.811 \mathrm{e}^{(0.094 T+0.071)} i^{1.632}
$$

where $y_{i T}$ is anchoveta egg age at stage $i$ and temperature $T\left({ }^{\circ} \mathrm{C}\right)$ observed at $10 \mathrm{~m}$ depth at each station. Egg ages then were assigned using the time of collection and assumed peak spawning time (22 h) following the automated procedure of Lo (1985).

Resulting age estimates from all eggs were then ordered in a frequency matrix of number of eggs by age $P_{i j}$ (see below) for the determination of $P_{0}$ and $Z$.

Determination of $\boldsymbol{P}_{\mathbf{0}}$ and $Z$. Daily egg production $P_{0}$ and natural mortality rates $Z$ in the main spawning area were estimated from an exponential decay model of egg abundance at age (in d) by non-linear regression. Natural mortality rate $Z$ was assumed constant for the entire main spawning area, and $P_{0}$ corresponds to egg abundance at egg Age 0

$$
P_{i j}=P_{0} \mathrm{e}^{(-Z t)}+\varepsilon_{i j}
$$

where $P_{i j}$ is egg abundance at egg age $y_{i T}$ at station $j, t$ is age in days, $P_{0}$ is daily egg production (eggs $\left.\mathrm{d}^{-1}\right), Z$ is instantaneous daily egg mortality rate $\left(\mathrm{d}^{-1}\right)$, and $\varepsilon_{i j}$ is additive error.

Euphausiid abundance. Zooplankton samples collected with CUFES and CalVET were used as indicators of euphausiid presence/absence in the upper layer because of the small volume of water sampled with these devices and because CUFES only collects at a single depth $(3 \mathrm{~m})$. Values obtained from the upper $50 \mathrm{~m}$ layer (53.6 ind. $\mathrm{m}^{-3}$ or 134 ind. $0.05 \mathrm{~m}^{-2}$ ) with Tucker Trawl Nets (1 $\mathrm{m}^{2}$ mouth opening) reported by Gonzalez et al. (2000) from the same study area were used as values of euphausiid abundance. These values were corrected by a 'capturability coefficient' obtained as the ratio of positive nocturnal stations over all nocturnal stations sampled in our winter 2000 cruise (sampled using CUFES or CalVET). The ratio involved only nocturnal stations because euphausiids show a normal vertical migration pattern in which they ascend to the shallower layer at night.

Immune sera production and anchoveta protein detection. To produce the anti-egg immune sera, 2 
white rabbits were immunizated with anchoveta egg proteins. Neither showed natural antibodies against egg proteins. The immune serum was obtained 2, 3 and $5 \mathrm{wk}$ after the first immunization, and was then separated, aliquoted, and frozen at $-80^{\circ} \mathrm{C}$ until use for egg protein detection in the guts of euphausiids collected during the egg survey.

In the laboratory, euphausiids were dissected on glass slides to extract their stomach and hind-gut (hereafter 'guts'), which were then placed in individual microtubes. Between 1 and 26 euphausiids (size range 9.2 to $29.5 \mathrm{~mm}$.) were dissected by station. Guts were homogenized with a glass tissue homogenizer in $500 \mu$ of phosphate-buffered saline (PBS, $10 \mathrm{mM} \mathrm{pH}$ 7.4), and then refrigerated overnight at $4^{\circ} \mathrm{C}$. Each tube was centrifuged at $4000 \times g\left(4^{\circ} \mathrm{C}\right)$ and the supernatant was removed, aliquoted and frozen at $-80^{\circ} \mathrm{C}$. This supernatant was tested against immune sera in order to detect anchoveta egg proteins in the euphasiid guts using indirect ELISA. ELISA is an immunochemical technique that allows quantified concentration of an antigen (anchoveta egg proteins) in a sample using a specific antibody (e.g. immune sera). This antibody reacts with a second marked antibody that develops a colorimetric reaction that can be measured spectrophotometrically $(490 \mathrm{~nm})$. Testing for cross-reactions with proteins from eggs and larvae of 6 other species commonly found in Chilean coastal waters (Sardinops sagax, Strangomera bentincki, Merluccius gayi, Stromateus stellatus, Normanichthys crockeri and Hygophum bruuni) as well as for Engraulis ringens larvae was performed by electrophoresis and Western blotting. Briefly, we loaded $20 \mu \mathrm{g}$ of proteins per lane in 2 identical SDS-PAGE gels ( 7 to $20 \%$ ). Electrophoresis was conducted following the procedures of Laemmli (1970) at a constant current and voltage of $120 \mathrm{~V}$ for $2 \mathrm{~h}$. After electrophoresis, one of the SDS-PAGE gels was stained with a silver solution (Wray et al. 1981). Details of this gel are described in Krautz et al. (2003). Proteins in the second gel were transferred to nitrocellulose paper according to Towbin et al. (1979), and were then incubated with an enzyme marked antibody (peroxidase-labelled goat anti-rabbit IgG) that reacts with substrate in a similar way as does ELISA. Positive reactions were detected by the presence of obscure bands in nitrocellulose paper. Cross-reactions (positive reaction between antibody and euphausiid gut content proteins) were discarded in almost all tested species. Weak reactions were detected in $S$. bentincki and $S$. sagax eggs only at high protein concentrations and lower serum dilution, which were efficiently controlled by applying a high dilution ratio $(1: 15000)$ to the serum. Further details on ELISA and immune sera production can be found in Krautz
(2003) and Krautz et al. (2003). Mean detection time of anchoveta egg proteins in euphausiids guts was $9 \mathrm{~h}$ (Krautz et al. 2003).

Anchoveta eggs consumed. Two methods were utilized to estimate numbers of anchoveta eggs consumed by euphausiids. The first method was based on Bailey et al. (1993), where egg consumption is calculated as

$$
C_{\mathrm{E}}=\frac{A_{\mathrm{C}} \times P_{\mathrm{E}} \times \mathrm{N}_{\mathrm{B}} \times V}{D_{13^{\circ} \mathrm{C}}}
$$

where $C_{\mathrm{E}}$ is egg consumption, $A_{\mathrm{C}}$ is predator (euphausiids) abundance in the area (ind. $0.05 \mathrm{~m}^{-2}$ ) corrected by capturability coefficient (explained in 'Euphausiid abundance' above), $P_{\mathrm{E}}$ is the ratio of euphausiids with positive response to antigen (anchoveta eggs), $\mathrm{N}_{\mathrm{B}}$ is number of eggs per euphausiid stomach (we assumed a minimum number of 1 egg per euphausiid), $V$ is the correction factor for the vertical overlap of predators and preys (we used the fraction of the day in hours when euphausiids and eggs cooccurred in the 0 to $70 \mathrm{~m}$ stratum: e.g. $t(\mathrm{~h})_{0}-70 \mathrm{~m} \times$ $24 \mathrm{~h}^{-1}$ ), and $D$ is detection time (in d) for egg proteins in euphausiid guts.

The second method was based on Theilacker et al. (1993), who utilized a Poisson distribution to obtain the average number of occurrences of ingestion events per interval $(\mu)$ obtained from the number of 'no ingestion' events $(X=0)$; that is

$$
P_{\mathrm{E}(X=0)}=\mathrm{e}^{-\mu}
$$

The number of eggs ingested per hour was calculated as the ratio of $\mu$ to protein detection time (determined from feeding experiments; see Krautz et al. 2003). These values were incorporated into a consumption equation

$$
C_{\mathrm{E}}=A_{\mathrm{C}} \times \mathrm{N}_{\mathrm{T}} \times t_{0-70 \mathrm{~m}}
$$

where $C_{\mathrm{E}}$ is egg consumption based on Theilacker et al. (1993), $\mathrm{N}_{\mathrm{T}}$ is number of anchoveta eggs consumed per euphausiid $\mathrm{h}^{-1}$, and $t_{0-70 \mathrm{~m}}$ is time of euphausiid residence $(\mathrm{h})$ in the upper stratum $(0-70 \mathrm{~m})$.

Mortality by predation $\boldsymbol{M}_{\mathbf{p}}$. Results from both methods were utilized to estimate the mortality rate from predation as

$$
M_{\mathrm{P}}=C_{\mathrm{EA}} \times P_{0 \mathrm{~A}}^{-1}
$$

where $C_{\mathrm{EA}}$ is total consumption of anchoveta eggs in the main spawning area $\left(C_{\mathrm{E}} \times\right.$ spawning area [n mile ${ }^{2}$ ) and $\mathrm{P}_{0 \mathrm{~A}}$ is daily egg production of anchoveta in the main spawning area $\left(P_{0} \times\right.$ spawning area $\left[\mathrm{n}\right.$ mile $\left.\left.^{2}\right]\right)$. Finally, the incidence of predation on total natural mortality was obtained from the ratio of $M_{\mathrm{P}}$ to $Z$ (natural mortality rate, $Z$, was obtained from the exponentially decreasing curve of egg abundance at age determined from DEPM in the main spawning area). 


\section{RESULTS}

\section{Anchoveta egg distribution}

In the total surveyed area, anchoveta eggs occurred at 127 out of 292 stations sampled (35.3\%) (Fig. 2). Total spawning area was determined from geostatistical analyses. The map obtained by kriging (Fig. 3A) shows the isoline of 1 egg $0.05 \mathrm{~m}^{-2}$ that was used to define total spawning area. The variograms obtained in the geostatistical analysis of egg distribution (structural analysis) (Fig. 3B) did not show anisotropy. Accordingly, an omnidirectional standardized variogram was used. The exponential fit gave a theoretical range (i.e. spatial scale of the egg patch, defined as the minimum distance in which autocorrelation occurs among stations) of $0.1564^{\circ}$ (ca. $9.4 \mathrm{n}$ mile)

Total spawning area was calculated to be 7963.02 $\mathrm{n}$ mile $^{2}$. Within this area, 2 sub-areas were identified according to the egg abundance observed: a northern sub-area with higher egg abundance (main spawning area) and a southern sub-area with lower egg abundance. The main spawning area covered 6301.4 $\mathrm{n}$ mile $^{2}$, and was located south of Iquique between $20.5^{\circ} \mathrm{S}$ and $22.5^{\circ} \mathrm{S}$. Mean egg concentration in this area was 65.8 eggs $0.05 \mathrm{~m}^{-2}$ with a peak value of 518 eggs $0.05 \mathrm{~m}^{-2}$. The closest-to-shore stations ( $1 \mathrm{n}$ mile) where eggs were found were also located between Caleta Loa $\left(21^{\circ} 30^{\prime} \mathrm{S}\right)$ and Tocopilla $\left(22^{\circ} \mathrm{S}\right)$. The second sub-area, where eggs were more dispersed, was localized south of $23^{\circ} \mathrm{S}$, and had a mean egg concentration of 48.2 eggs $0.05 \mathrm{~m}^{-2}$ and a peak concentration of 392.8 eggs $0.05 \mathrm{~m}^{-2}$. In this area, eggs were mainly located further than $15 \mathrm{n}$ mile from shore (Fig. 2A).

\section{Daily egg production $P_{0}$ and natural mortality $Z$}

Using an exponential decay model of egg abundance at age, a natural mortality rate of $Z=0.868 \mathrm{~d}^{-1}$ $(\mathrm{SE}=0.335)$ and daily egg production rate (intercept, $\left.P_{0}\right)$ of 42.86 eggs $0.05 \mathrm{~m}^{-2} \mathrm{~d}^{-1}(\mathrm{SE}=12.55)$ was obtained for the main spawning area $(\mathrm{p}<0.01)$. Based on these results, $P_{0}$ of the main spawning area was estimated to be $1.86 \times 10^{13}$ eggs d ${ }^{-1}$ (Table 1 ).

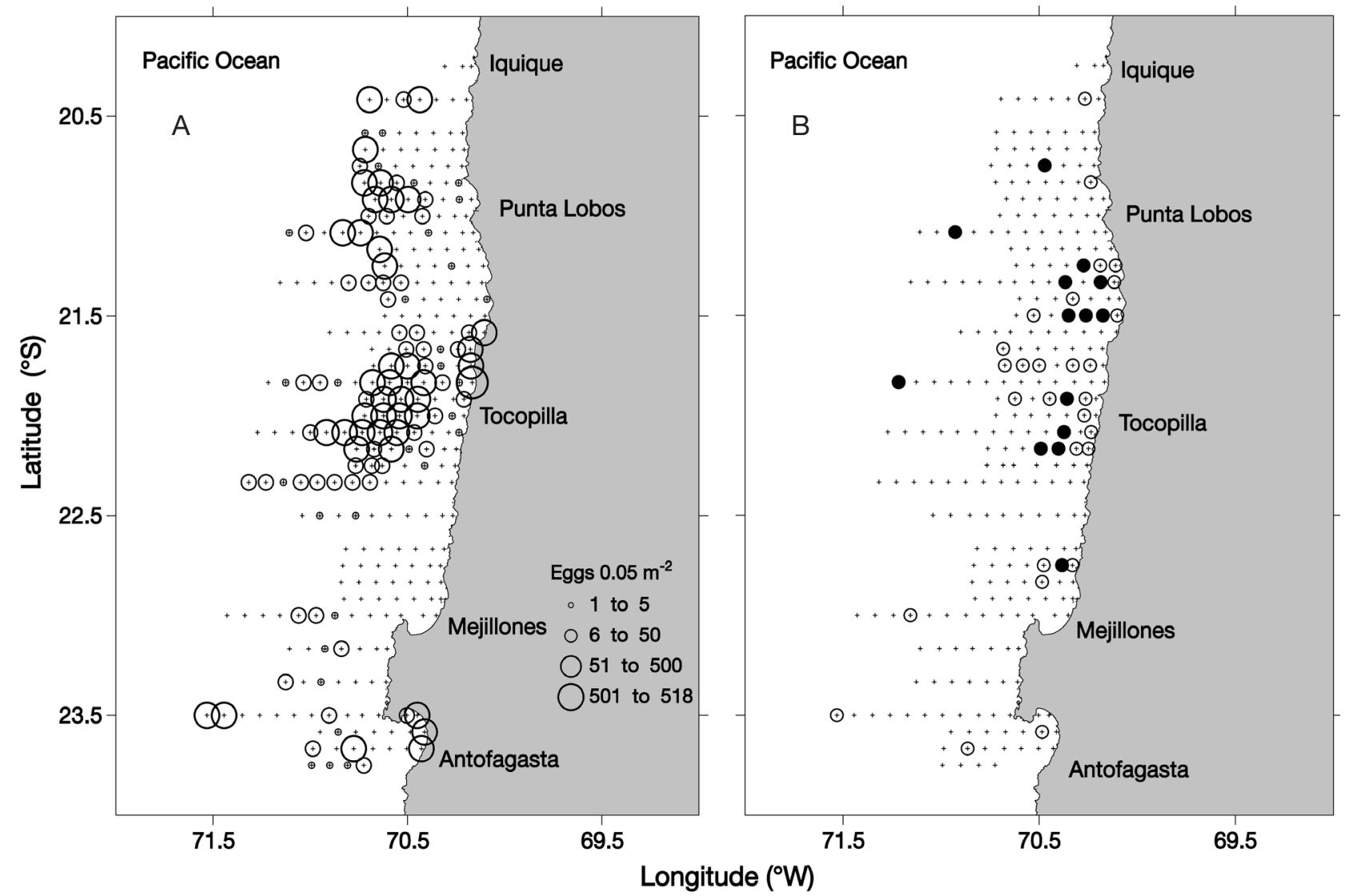

Fig. 2. (A) Engraulis ringens. Stations (O) where eggs were collected. Circle diameter represents egg abundance. (B) Euphausia mucronata. Position of stations $(0, \bullet)$ with positive euphausiid capture. •: positive response of euphausiids gut to immunoassay, $\mathrm{O}$ : negative responses of euphausiids gut to immunoassay 


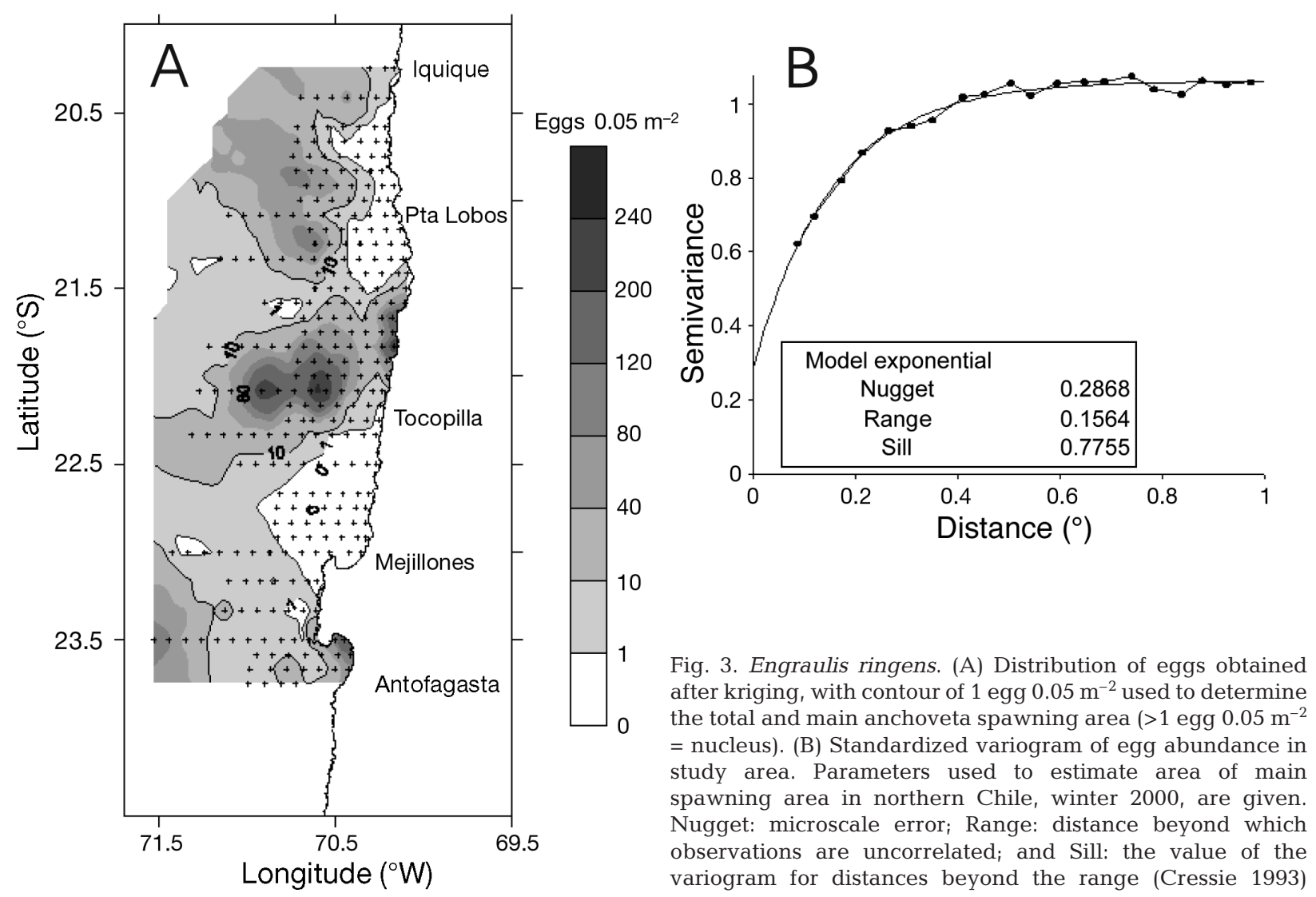

Table 1. Engraulis ringens. Egg production estimated by DEPM in main spawning area, egg consumption by Euphausia mucronata and the fraction of total egg natural mortality rate $(Z)$ exerted by euphausiid predation $\left(M_{\mathrm{P}}\right)$

\begin{tabular}{|c|c|c|c|c|c|c|}
\hline $\begin{array}{l}\text { Egg production } \\
\text { (eggs } 0.05 \mathrm{~m}^{-2} \text { ) }\end{array}$ & $\begin{array}{l}\text { Total egg production } \\
\text { in main spawning } \\
\text { area }\left(\text { no. } d^{-1}\right)\end{array}$ & $\begin{array}{l}\text { Egg consumption } \\
\left.\text { (eggs } 0.05 \mathrm{~m}^{-2}\right)\end{array}$ & $\begin{array}{l}\text { Total egg consumption } \\
\text { in main spawning } \\
\text { area }\left(\text { no. } d^{-1}\right)\end{array}$ & $M_{\mathrm{P}}\left(\mathrm{d}^{-1}\right)$ & $Z\left(\mathrm{~d}^{-1}\right)$ & $\%\left(M_{\mathrm{P}} \times Z^{-1}\right)$ \\
\hline \multicolumn{7}{|c|}{ Based on Bailey et al. (1993) } \\
\hline 42.86 & $1.86 \times 10^{13}$ & 9.025 & $3.90 \times 10^{12}$ & 0.211 & 0.868 & 24.26 \\
\hline \multicolumn{7}{|c|}{ Based on Theilacker et al. (1993) } \\
\hline 42.86 & $1.86 \times 10^{13}$ & 10.215 & $4.40 \times 10^{12}$ & 0.238 & 0.868 & 27.46 \\
\hline
\end{tabular}

\section{Euphausiid distribution}

Euphausiids were mainly captured in nocturnal and coastal stations between Punta Lobos $\left(21^{\circ} \mathrm{S}\right)$ and Tocopilla $\left(22^{\circ} \mathrm{S}\right)$ (Fig. 3), coinciding with the location of the main anchoveta spawning area. We also collected euphausiids from several oceanic stations (60 n mile from shore). Euphausiids occupy the upper 0 to $70 \mathrm{~m}$ layer for $11 \mathrm{~h}$ ascending near 19:00 $\mathrm{h}$ and descending to the deep layer again at around 06:00 h (Fig. 4). Accordingly, we used the period that corresponds to the fraction of the day of spatial overlap between anchoveta eggs and euphausiids (0.458) as one of the parameters to estimate mean predator abundance and numbers of anchoveta eggs consumed by predation (see algorithms proposed by Bailey et al. 1993). Another correction factor in the predation algorithms is the ratio of positive nocturnal stations to all nocturnal stations. In our study, this correction factor corresponded to a value of 0.3143 .

\section{Immunoassays in laboratory experiments and field- collected euphausiids}

ELISA detected cross-reaction of the serum with egg proteins for 3 fish species (Sardinops sagax, Strangomera bentincki and Merluccius gayi) and the 


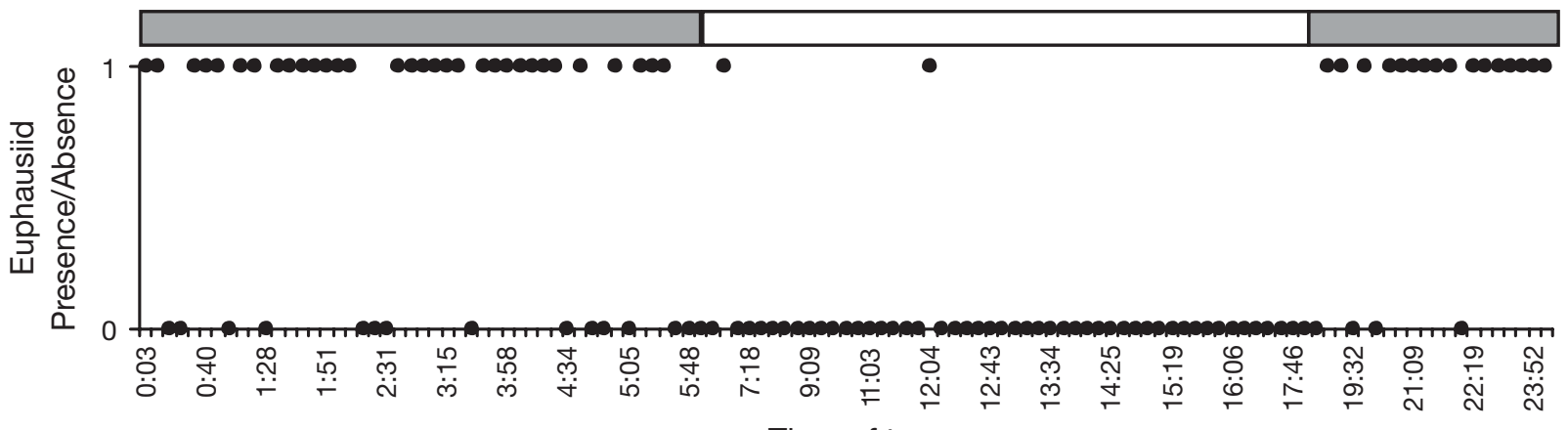

Time of tow

Fig. 4. Euphausia mucronata. Presence/absence in zooplankton samples collected during day and night hours in northern Chile. $1=$ presence, 0 = absence; dark grey bars indicate night hours

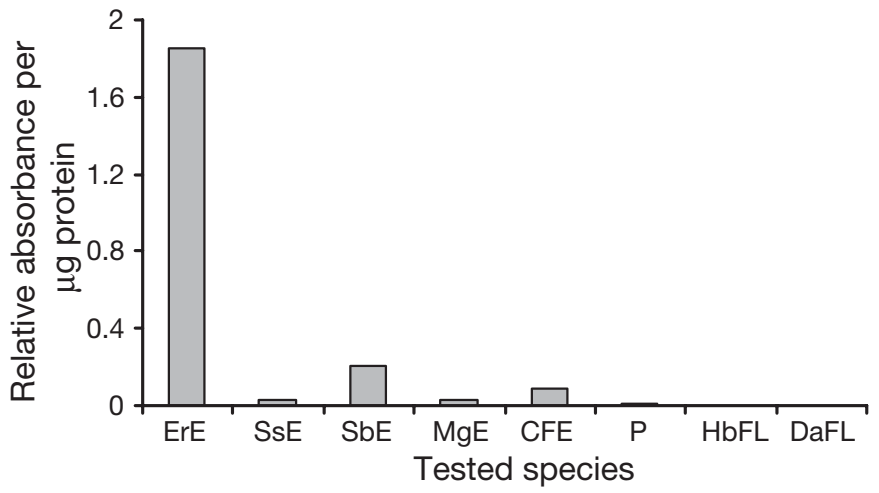

Fig. 5. Cross-reactions. Relative absorbance per $\mu \mathrm{g}$ protein of Engraulis ringens eggs and co-occurring species. ErE: E. ringens eggs; SsE: Sardinops sagax eggs; SbE: Strangomera bentincki eggs; MgE: Merluccius gayi eggs; CFE: coastal fish (mix) eggs; P: phytoplankton; HbFL: Hygophum bruuni fish larvae; DaFL: Diogenichthys atlanticus fish larvae

mixture of eggs from coastal species, but only at very high concentrations ( $>30 \mu \mathrm{g} \mathrm{ml}^{-1}$ ) (Fig. 5). The myctophiids Hygophum bruuni and Diogenichthys atlanticus and phytoplankton did not show clear responses to the serum even at this high concentration. In contrast, the response of anchoveta eggs to the serum occurred over a wide range of concentrations and down to a very low absorbance detection limit (cut-off value of absorbance $=0.273$ ). Thus, the dilution ratio of 1:15000 of the high titre immune serum detected anchoveta egg proteins down to a concentration of $1 \mu \mathrm{g} \mathrm{ml}^{-1}$ and avoided cross-reactions with proteins from other species that were detected only at higher concentrations.

Experiments evaluating euphausiid predation on anchoveta eggs indicated a window of egg protein detection of $9 \mathrm{~h}\left(13^{\circ} \mathrm{C}\right.$, temperature within the base of the thermocline in the study area; see Krautz 2003 and Krautz et al. 2003). The exponential model of protein content decrease in euphausiid guts showed a decay rate of $-0.0385 \mathrm{~h}^{-1}(\mathrm{SE}=0.0104)$ and a $G_{0}$ of $0.4226 \mu \mathrm{g}$ protein $\left(G_{0}\right.$ is the quantity of protein per euphausiid at the beginning of the evacuation experiment). The percent variance explained by the model was $28.09 \%$ $(\mathrm{p}<0.001)$.

Anchoveta egg remains were detected in $18 \%$ of 158 euphausiids tested. These positive responses were located in 14 of the 42 (33\%) stations where euphausiids were found (from a total of 292 stations surveyed from 20 to $23^{\circ} \mathrm{S}$ ). Of those 14 stations with positive reactions, 11 were located inside the main spawning area. The average quantity of egg protein inside euphausiid guts was $0.199 \mu \mathrm{g}(\mathrm{SE}=0.016)$, which corresponded to $0.07 \%$ of total proteins in euphausiid guts.

\section{Euphausiid predation estimates}

Based on the algorithms of Bailey et al. (1993), we estimated an egg consumption of 9.02 eggs $0.05 \mathrm{~m}^{-2}$ $\mathrm{d}^{-1}$, which when extrapolated to the main spawning area gave a total egg consumption of $3.9 \times 10^{12}$ eggs in the nucleus. The potential predator incidence (ratio of euphausiid egg consumption to egg production) in the main spawning area was 0.211 , accounting for $24.3 \%$ of natural mortality in the nucleus (Table 1).

Using the algorithms proposed by Theilacker et al. (1993), we estimated the frequency of assays negative to anchoveta egg proteins (negative ELISA, 0.8193) and the quantity of eggs consumed by each euphausiid $\left(0.1193\right.$ eggs euphausiid $\left.{ }^{-1}\right)$. This value was corrected by the protein time detection $(9 \mathrm{~h}=0.345 \mathrm{~d})$ to give an ingestion rate of 0.022 eggs euphausiid ${ }^{-1} \mathrm{~h}^{-1}$. Calculated egg consumption was 10.2 eggs $0.05 \mathrm{~m}^{-2}$ and $4.4 \times 10^{12}$ eggs d $^{-1}$ in the main spawning area. The percent of total mortality accounted for by predation was $27.5 \%$ (Table 1 ). 


\section{DISCUSSION}

Engraulis ringens and Euphausia mucronata are key species in the Humboldt Current and transport a large fraction of biological production from the photic zone through processes of grazing, predation, vertical migration, and pellet exportation. During the anchoveta spawning season (mid-winter to spring, Castro et al. 2000), anchoveta egg and larvae co-exist at night with the very abundant, vertically migrating euphausiids that rise every evening to the shallower layer to feed. Although euphausiid egg consumption was expected, it had never been quantified in the Humboldt System due to limitations of appropriate techniques to quantify predation. In this study, we followed the approach developed by Theilacker et al. (1993) and Bailey et al. (1993) to apply indirect ELISA and the production of a polyclonal antibody to euphausiid gut contents, in order to quantify the impact of euphausiid predation on the largest anchoveta egg aggregation in northern Chile during the anchoveta main spawning season in the Humboldt Current. Our results revealed Euphausia mucronata to be a significant predator of anchoveta eggs, responsible for about $25 \%$ of total daily egg mortality.

Some of the factors that affect methods to determine predation are the estimation of prey abundance, predator abundance and their overlap in time and space, assumptions, limitations and sensibility of analytical techniques, and potential interferences (crossreactions) with alternative non-target prey. In this study, we quantified egg abundance using a dense sampling grid designed to estimate spawning biomass of anchoveta in northern Chile through DEPM in 2000. This fine grid $(5 \times 5 \mathrm{n}$ mile) included 292 stations from which ichthyoplankton samples were collected within a depth range that is wider than that usually utilized by anchoveta. Consequently, anchoveta eggs were not expected below the sampled depth because this species normally resides in the shallower layer of the water column, above the oxygen minimum zone (oxycline occurs at ca. 20 to $50 \mathrm{~m}$ depth, Gonzalez et al. 2000). Unfortunately, good simultaneous estimations of euphausiid abundance in the field were not available in our study (our euphausiid collections were used only for presence/absence analyses and for immunoassays). Consequently, our abundance values had to be based on values reported in the literature for this zone during non-El Niño conditions (Gonzalez et al. 2000). The data utilized were obtained from tucker trawl $\left(1 \mathrm{~m}^{2}\right.$ mouth opening) oblique tows conducted in the shallower $50 \mathrm{~m}$ of the water column, which is the depth range where anchoveta eggs occur and the depth range to which euphausiids normally migrate every night, as shown in Fig. 4. In this study, the distribution of predators and prey also overlapped in the horizontal plane. Moreover, about $79 \%$ of stations whose euphausiids presented positive reactions to the egg protein occurred in the main spawning area. These results are interesting in that they suggest there might be some type of predator-prey distributional association (i.e. predators following their prey), or that both organisms may be responding to the same environmental clue or may be affected by the same oceanographic processes that shape their horizontal distribution. A somewhat similar situation was observed by Theilacker et al. (1993) in the California Current, where they estimated an even higher incidence of euphausiid predation in the area of higher northern anchovy egg and larval abundance (coastal zone; ca. $78 \%$ of total mortality in the coastal zone was due to euphausiid predation). However, we suspect that these co-occurring distributions and high predation incidences in the main spawning area are not always the rule in all upwelling areas, because there are also reports of euphausiid distributions that do not exactly coincide with either areas of peak anchoveta egg abundances (i.e. northern Peru) or with areas of high concentrations of sardine eggs (i.e. California Current) (Checkley et al. 2000).

The egg consumption methods of this study used 2 criteria to determine the number of eggs ingested by euphausiids, which permitted calculation of an individual ingestion rate even when the quantity of targeted egg proteins had not been constant during egg development or within the euphausiid gut. A decrease in egg protein quantity during embryo development has been associated with the generation of energy and embryonic growth (Rønnestad et al. 1992, Okhubo \& Matsubara 2002) and to the regulation of egg buoyancy through amino acid consumption (Thorsen \& Fhyn 1996, Thorsen et al. 1996). The first criteria in our study considered a conservative minimum of 1 egg ingested per euphausiid in those euphausiids with positive immunoassays, and then applied the frequency of positive tests to the total number of euphausiids present (Bailey et al. 1993). In the second criteria, the determination of an average number of ingested eggs per predator was based on the frequency of negative signals to immunoassays (Theilacker et al. 1993). Interestingly, both approaches lead to a similar estimation of egg consumption in the main area of egg abundance $\left(3.9 \times 10^{12}\right.$ and $4.4 \times 10^{12}$ eggs, respectively) and corresponded to estimations of total natural mortality due to predation of 24.3 and $27.5 \%$, respectively.

Estimation of egg consumption by euphausiids is dependent on the time-frame during which it is possible to detect egg protein remains in euphausiid stomachs. We determined a protein detection time of $9 \mathrm{~h}$ $\left(13^{\circ} \mathrm{C}\right.$, Krautz et al. 2003). Theilacker et al. (1993) used enzyme-linked immunospot assay (ELISPOT) to 
achieve an Engraulis mordax egg protein detection time of $7 \mathrm{~h}$ with a lineal decrease in the percentage of positive responses to assays. Bailey et al. (1993) reported $4 \mathrm{~h}\left(6^{\circ} \mathrm{C}\right)$ to be the detection time required for Theragra chalcogramma egg proteins. In all studies (ours included), authors utilized the time to $50 \%$ protein decrease as the egg consumption estimate. Using a model of exponential decrease of gut contents over time, an experimental rate of egg protein decrease in the euphausiid stomach of $0.0385 \mathrm{~h}^{-1}$ was obtained. In comparison, chlorophyll a concentrations decrease at a rate of 0.22 to $0.7 \mathrm{~h}^{-1}$ in the guts of Euphausia mucronata in the same area of the Humboldt Current off northern Chile (Gonzalez et al. 2000). Proteins are digested very quickly in organisms, and consequently our detection in euphausiid stomachs over prolonged periods could be attributed to the high sensitivity of ELISA and to the potential storage role of the digestive gland, as proposed for other arthropods (Quinlan et al. 1993). In other groups of invertebrates (Sepia officinallis), a variability in detection time of 1 to $8 \mathrm{~h}$ was observed depending on the digestive organ analyzed (e.g. stomach, mid-gut gland, intestine) (Kear \& Boyle 1992). Thus, the high specificity and high sensibility of this method may be of great importance to the determination of recent-past predation. For instance, at the moment of collection, predators and preys may not be found together (i.e. due to vertical migrations or shortterm horizontal displacements by surface currents), or hard parts may no longer be visible in the intestine after some period of digestion, as is the case for many crustaceans that finely macerate their prey.

The high titre serum that we produced reacted strongly with anchoveta egg yolk, whereas it reacted weakly with proteins from several other fish species. A similar observation was made by Theilacker et al. (1993), who detected weak cross-reactions of their antibody to northern anchovy eggs with pacific mackerel Scomber japonicus eggs. Because crossreactions were only detected under high protein concentration and lower serum dilution, cross-reactions with proteins from other fish species were efficiently controlled by applying a high dilution ratio $(1: 15000)$ to the serum. Additionaly, our polyclonal antibody did not react with non-yolked anchoveta (post-flexion) larvae or with larvae from other common species in the study area.

During peak anchoveta spawning of 2000, we estimated a daily egg production rate $\left(P_{0}\right)$ of 42.86 eggs $0.05 \mathrm{~m}^{-2} \mathrm{~d}^{-1}$ and a natural egg mortality rate $(Z)$ of $0.868 \mathrm{~d}^{-1}$ in the main spawning area of the northern Chilean anchoveta stock. As expected, the estimated egg production rate was higher in the main spawning area than in the entire spawning area during the same year $\left(P_{0}=29.7\right.$ eggs $\left.0.05 \mathrm{~m}^{-2} \mathrm{~d}^{-1}\right)$ (Table 2$)$, but was within the upper range reported for the entire area in other years. In turn, the estimated natural egg mortality rate for the main spawning area in 2000 was slightly higher than that for the overall area during the same year $\left(0.78 \mathrm{~d}^{-1}\right)$, and was also within the upper range reported for most years. Anchoveta egg mortality rates estimated from northern Peru $\left(0.91 \mathrm{~d}^{-1}\right.$, Santander et al. $1983 ; 1.12 \mathrm{~d}^{-1}$, Smith et al. 1989) were higher than our estimates from the main spawning area and entire area off northern Chile. Our estimates from northern Chile were higher than those from southern Chile $\left(0.526 \mathrm{~d}^{-1}\right.$, Cubillos et al. 2003). Because the estimates mentioned above (northern Peru, northern Chile, southern Chile) were made in different years, the existence of a trend in egg mortality rates among populations (i.e. decrease with latitude) cannot be reliably proposed, even though it is known that other trends exist in e.g. anchoveta stock size and egg production (largest stock in northern Peru, medium size stock in southern Peru-northern Chile, smallest stock in southern Chile). Other trends, such as a decrease in egg volume with latitude in peak spawning seasons, have also been described along the Humboldt Current for anchoveta (Llanos-Rivera \& Castro 2004).

In marine systems, the relative importance of predation can be obtained from comparison of values of total natural mortality rates with those of predation (Vetter 1988). In this study, we calculated that 24 to $27 \%$ of total natural Engraulis ringens egg mortality resulted from predation by the euphausiid Euphausia mucronata. These results are lower than those reported in other upwelling systems such as the California Current, where Theilacker et al. (1993) calculated predation incidence by the entire euphausiid community on Engraulis mordax eggs and larvae to be between 47 and $78 \%$ of total natural mortality. Bailey et al. (1993) obtained predation incidences exerted by euphausiids on the standing stock of Theragra chalcogramma eggs of $0.2 \%$ in the Gulf of Alaska, and calculated that between 0.8 to $1.2 \%$ of total daily egg

Table 2. Engraulis ringens. Estimates of egg production $\left(P_{0}\right)$ and natural mortality $(Z)$ rates in the spawning area in northern Chile from 1996 to $2003\left(18^{\circ} 20^{\prime} \mathrm{S}\right.$ to $\left.23^{\circ} 03^{\prime} \mathrm{S}\right)$ (modified from Braun et al. 2004)

\begin{tabular}{|lcc|}
\hline $\begin{array}{l}\text { Year of } \\
\text { assessment }\end{array}$ & $\begin{array}{c}P_{0} \pm \mathrm{SE} \\
\left(\text { eggs } 0.05 \mathrm{~m}^{-2} \mathrm{~d}^{-1}\right)\end{array}$ & $\begin{array}{c}Z \pm \mathrm{SE} \\
\left(\mathrm{d}^{-1}\right)\end{array}$ \\
\hline 1996 & $15.8 \pm 4.68$ & $0.48 \pm 0.20$ \\
1997 & $14.9 \pm 4.74$ & $0.44 \pm 0.37$ \\
1999 & $23.0 \pm 8.18$ & $0.78 \pm 0.24$ \\
2000 & $29.7 \pm 7.06$ & $0.77 \pm 0.17$ \\
2001 & $30.2 \pm 29.37$ & $0.80 \pm 0.52$ \\
2002 & $15.9 \pm 3.04$ & $0.62 \pm 0.15$ \\
2003 & $37.1 \pm 16.03$ & $0.83 \pm 0.30$ \\
& & \\
\hline
\end{tabular}


mortality resulted from predation by a mixture of pelagic crustaceans (gammarids, hyperiids, mysidaceans, and euphausiids) in the same area. Thus, our natural mortality rate estimates due to predation fall mid-range of those reported by the few other studies on crustacean predators that have used immunoassays to estimate predation rates.

Current approaches to understanding fluctuations in the huge abundance of anchoveta Engraulis ringens in the Humboldt Current include analyses of large scale oceanographic patterns, ecosystem-derived indices and fishery effort (Schwartzlose et al. 1999, Chavez et al. 2003). However, most likely owing to the scarce information available, less attention has been paid to understanding and quantifying interactions among key species, especially those interactions that occur during early life-stages of development (Muck et al. 1989). Our results reveal that one-fourth of the total natural mortality rate of anchoveta eggs might be due to predation exerted by 1 pelagic species, Euphausia mucronata, which is considered key in the pelagic trophic web and, along with anchoveta, transports much of the biological production into the euphotic zone. Estimates of egg mortality resulting from $E$. ringens cannibalism in Peru reach up to $21.9 \%$ of total natural egg mortality (Alheit 1987). Other estimates of cannibalism exerted by other anchovy species (Engraulis mordax) over their own eggs reached values higher than those obtained in the present study (up to $37 \%$ of daily egg production in the California Current, Hunter \& Kimbrell 1980). Thus, if both E. ringens and E. mucronata are considered together when investigating anchoveta egg natural mortality, an interesting picture emerges: combined, these key pelagic species might contribute to about half of the total mortality rate of anchoveta eggs in the Humboldt Current. Therefore, biological interactions during early life stages, such as predation between key pelagic species in this very productive coastal system, should be considered when interpreting the well-known fluctuations in anchoveta populations - some of the largest stocks of small pelagic fish in the world. In a broader context, our results may have interesting implications for classic trophic web models in any system (either community oriented or carbon-flux oriented), as well as for over-simplified interspecific interaction schemes depicting demographic control of dominant species in pelagic systems (i.e. predator-prey), in which biological interactions among young developmental stages are not contemplated.

Acknowledgements. We thank G. Claramunt, R. Escribano, S. Pantoja, R. González, R. Quiñones, and H. González for their collaboration during this study. We are also grateful to J. Oliva and the crew of RV 'Carlos Porter' from Instituto de
Fomento Pesquero for use of facilities during sample collection of the 2000 DEPM cruise. We also thank an anonymous reviewer for valuable comments on an earlier version of this manuscript. Authorization to use data presented in Table 2 was granted by Fondo de Investigación Pesquera. Financial support for this study was provided by FONDECYT grants 1990470 (to L.R.C., E. Tarifeño and R. Escribano) and 1010900 (to W. Schneider, R. Roa and L.R.C.), and by the FONDAPHumboldt Program.

\section{LITERATURE CITED}

Alheit J (1987) Egg cannibalism versus egg predation: their significance in anchovies. S Afr J Mar Sci 5:467-470

Bailey KM, Houde ED (1989) Predation on eggs and larvae of marine fishes and the recruitment problem. Adv Mar Biol 25:1-67

Bailey KM, Brodeur RD, Merati N, Yoklavick MM (1993) Predation on walleye pollock (Theragra chalcogramma) eggs and yolk-sac larvae pelagic crustacean invertebrates in the Western Gulf of Alaska. Fish Oceanogr 2:30-39

Braun M, Claramunt G, Reyes $\mathrm{H}$, Catasti V and 5 others (2004) Evaluación del Stock desovante de la anchoveta en la I y II Regiones, año 2003. Informe final Proyecto FIP 2003-07, Fondo de Investigación Pesquera, Valparaíso

Castro LR (2001) Studies on the environmental conditions and larval survival during the winter spawning season of the southernmost anchoveta stock off Chile. GLOBEC Newsl 7:15-17

Castro LR, Salinas GR, Hernández EH (2000) Environmental influences on winter spawning of the anchoveta Engraulis ringens off central Chile. Mar Ecol Prog Ser 197:247-258

Chavez FP, Ryan J, Lluch-Cota SE, Niquen M (2003) From anchovies to sardines and back: multidecadal change in the Pacific Ocean. Science 299:217-221

Checkley DM, Dotson RC, Griffith DA (2000) Continuous, underway sampling of eggs of Pacific sardine (Sardinops sagax) and northern anchovy (Engraulis mordax) in spring 1996 and 1997 off southern and central California. Deep Sea Res II 47:1139-1155

Cressie NA (1993) Statistics for spatial data. John Wiley \& Sons, New York

Cubillos L, Núñez S, Véjar F, Torres P and 14 others (2003) Evaluación del stock desovante de anchoveta y sardina común entre la V y X Regiones, año 2002. Informes Técnicos FIP, Fondo de Investigación Pesquera, Valparaíso

Cury P, Bakun A, Crawford RJM, Jarre A, Quiñones RA, Shannon LJ, Verheye HM (2000) Small pelagics in upwelling systems: patterns of interaction and structural changes in 'wasp-waist' ecosystems. J Mar Sci 57:603-618

Escribano R, Marín VH, Irribarren C (2000) Distribution of Euphausia mucronata at the upwelling area of Peninsula Mejillones, northern Chile: the influence of the oxygen minimum layer. Sci Mar 64:69-77

Fuenzalida R (1991) Proceso de surgencia en la región Norte de Chile, Latitudes $20^{\circ} 30^{\prime} \mathrm{S}-21^{\circ} 45^{\prime} \mathrm{S}$. Cien Mar 2:79-104

Gibbons MJ, Pillar SC, Stuart V (1991) Selective carnivory of Euphausia lucens in the southern Benguela. Cont Shelf Res 11:625-640

González HE, Sobarzo M, Figueroa D, Nöthing EM (2000) Composition, biomass and potential grazing impact of the crustacean and pelagical tunicates in the northern Humboldt Current area off Chile: differences between El Niño and non-El Niño years. Mar Ecol Prog Ser 195:201-220

Hunter J, Kimbrell C (1980) Egg cannibalism in the northern anchovy, Engraulis mordax. Fish Bull 78:811-816 
Isaaks EH, Srivastava RM (1989) Applied geostatistics. Oxford University Press, London

Kear AJ, Boyle PR (1992) Loss of meal antigenicity during ingestion in Sepia officinalis (Cephalopoda: Sepioidea). J Mar Biol Assoc UK 72:543-551

Krautz MC (2003) Predación de eufáusidos sobre huevos de anchoveta (Engraulis ringens Jenyns) en la zona norte de Chile estimada a través del uso de inmunoensayos. MSc dissertation, Universidad de Concepción (in Spanish with English abstract)

Krautz MC, González M, Castro LR (2003) Detection of anchoveta (Engraulis ringens) eggs in euphausiid diets using immunoassays (ELISA). J Exp Mar Biol Ecol 294: $27-39$

Laemmli UK (1970) Cleavage of structural proteins during the assembly of the head of bacteriophage T4. Nature 227: $680-685$

Llanos-Rivera A, Castro LR (2004) Latitudinal and seasonal egg size variation of the anchoveta (Engraulis ringens) off the Chilean coast. Fish Bull 102:207-212

Lo N (1985) A model for temperature-dependent northern anchovy egg development and an automated procedure for the assignment of age to staged eggs. In: Lasker $\mathrm{R}$ (ed) An egg production method for estimating spawning biomass of pelagic fish: application to the northern anchovy, Engraulis ringens. NOAA Tech Rep NMFS 36:43-50

Matheron G (1963) Principles of geostatistics. Econ Geol 58: 1246-1266

Moser HG, Ahlstrom EH (1985) Staging anchovy eggs. In: Lasker R (ed) An egg production method for estimating spawning biomass of pelagic fish: application to the northern anchovy, Engraulis mordax. NOAA-NMFS Tech Rep 36:37-41

Muck P, Rojas De Mendiola B, Antonietti E (1989) Comparative studies of feeding on larval anchoveta (Engraulis ringens) and sardine (Sardinops sagax). In: Pauly D, Muck P, Mendo J, Tsukyama Y (eds) The Peruvian upwelling ecosystem: dynamics and interactions. ICLARM Conf Proc 18. Instituto del mar del Peru (IMARPE), Callao, p 86-96

Okhubo N, Matsubara T (2002) Sequential utilization of free amino acids, yolk proteins and lipids in developing eggs and yolk-sac larvae of barfin flounder Verasper moseri. Mar Biol 140:187-196

Petitgas P (1996) Geostatistics and their applications in fisheries survey data. In: Megrey BA, Moksness E (eds) Computers in fisheries research. Chapman \& Hall, London

Picquelle S, Stauffer G (1985) Parameter estimation for an egg production method of northern anchovy biomass assessment. In: Lasker R (ed) An egg production method for estimating spawning biomass of pelagic fish: application to the northern anchovy, Engraulis ringens. NOAA Tech Rep NMFS 36:7-15

Quinlan TC, Calver MC, Smith GT (1993) Immunological

Editorial responsibility: Otto Kinne (Editor-in-Chief), Oldendorf/Luhe, Germany determination of digestive rates in the synoptic scorpions Urodactus armatus Pocock and Urodacus novahollandiae Peters. Oecologia 95:459-462

Rønnestad I, Fyhn HJ, Gravningen K (1992) The importance of free amino acids to energy metabolism of eggs and larvae of turbot (Scophtalmus maximus). Mar Biol 114: $517-525$

Santander H, Alheit J, MacCall V, Alamo V (1983) Egg mortality of the Peruvian anchovy (Engraulis ringens) caused by cannibalism and predation by sardine (Sardinops sagax). FAO Fish Rep 291:1011-1025

Schwartzlose RA, Alheit V, Bakun V, Baumgartner V and 17 others (1999) Worldwide large-scale fluctuations of sardine and anchova populations. S Afr J Mar Sci 21:289-347

Serra J, Rojas O, Aguayo M, Inostroza F, Cañon J (1979) Anchoveta (Engraulis ringens). In: Estado actual de las principales pesquerías nacionales. Bases para un desarollo pesquero. Corporación de Fomento de la Producción. Instituto de Fomento Pesquero, Santiago

Smith PE, Santander H, Alheit J (1989) Comparison of the mortality rates of Pacific sardine, Sardinops sagax, and Peruvian anchovy, Engraulis ringens, eggs off Peru. Fish Bull 87:497-508

Soto SA, Claramunt G, Escribano R (2005) Temperaturedependent development rate of eggs of the southern anchoveta Engraulis ringens. In: Castro LR, Freon P, van der Lingen CD, Uriarte A (eds) Report of the SPACC meeting on small pelagic fish spawning habitat dynamics and the daily egg production method (DEPM). GLOBEC Rep 22:51-53

Theilacker GH, Lasker R (1974) Laboratory studies of predation by euphausiid shrimps on fish larvae. In: Blaxter JHS (ed) The early life history of fish. Springer Verlag, Berlin, pp 287-300

Theilacker GH, Lo NCH, Townsend AW (1993) An immunochemical approach to quantifying predation by euphausiids on the early stages of anchovy. Mar Ecol Prog Ser 92: $35-50$

Thorsen A, Fyhn HJ (1996) Final oocyte maturation in vivo and in vitro in marine fishes with pelagic eggs: yolk protein hydrolysis and free amino acid content. J Fish Biol 48: 1195-1209

Thorsen A, Kjesbu OS, Fyhn HJ, Solemdal P (1996) Physiological mechanisms of buoyancy in eggs from brackish water cod. J Fish Biol 48:457-477

Towbin H, Staehelin T, Gordon J (1979) Electrophoretic transfer of proteins from polyacrilamide gels to nitrocellulose sheets: procedure and some applications. Proc Natl Acad Sci 76:4350

Vetter EF (1988) Estimation of natural mortality in fish stocks: a review. Fish Bull 86:25-43

Wray W, Boulikas T, Wray VP, Hancock R (1981) Silver staining of proteins in polyacrylamide gels. Anal Biochem 15: 197-203

Submitted: August 8, 2005; Accepted: July 3, 2006

Proofs received from author(s): March 28, 2007 